\title{
Network Neutrality: Lessons from Transportation
}

\author{
DAVID LEVINSON * \\ Department of Civil Engineering, University of Minnesota
}

\begin{abstract}
The politically-charged notion of network neutrality came to the fore in the first decade of the 21st century, using analogy from transportation as one of the key tools in motivating arguments. This paper examines how the various notions around network neutrality (common carriage, regulation, price discrimination) have historically played out in the transportation sector, and suggests some of the current arguments fail to understand the nuances of how complex networks actually operate to serve the many demands placed on them.
\end{abstract}

\section{Introduction}

Advocacy group Save the Internet asserts: "Net Neutrality ensures that all users can access the content or run the applications and devices of their choice. With Net Neutrality, the network' only job is to move data - not choose which data to privilege with higher quality service. Net Neutrality prevents the companies that control the wires from discriminating against content based on its source or ownership."”

This argument has been enmeshed in a public debate as providers of internet connections seek to charge the senders of data for data transmitted over their wires to their customers. Some in favor of neutrality argue the customers have already paid an access charge for internet service, and should be able to receive bits of data from anywhere connected to the internet, with no differentiation in the quality of service those bits receive. An example of this argument can be seen in the following quote: "So imagine if turnpikes charged when you got on the road, and then again when you got off. This is exactly what some of the telcos are trying to do with internet access. They see that internet access is a commodity and decreasing revenue from the cash-cow that is circuit based voice service and are looking for new sources of revenue ... ".2 Similarly, Frankston satirically imagines "Transportation Service Providers" charging for sidewalks in front of people's houses. ${ }^{3}$ Again in that vein: Crawford writes "Think of the pipes and wires that you use to go online

\footnotetext{
* Mailing address. University of Minnesota, Department of Civil Engineering, 500 Pillsbury Drive SE, Minneapolis, MN 55455 USA, Email: dlevinson@umn.edu

${ }^{1}$ Save the Internet. 2006. "Frequently Asked Questions,” http://www.savetheinternet.com/=faq

2 “The Jeff Pulver Blog January 29, 2006,” http://pulverblog.pulver.com/archives/003599.html

${ }^{3}$ Bob Frankston "Sidewalks: Paying by the Stroll," Posted May 25, 2006

http://www.frankston.com/Public/Default.aspx?zz=xcs\&Script_name=\%2Fdefault.aspx\&name=Sidewalks
} 
as a sidewalk. The question is whether the sidewalk should get a cut of the value of the conversations that you have as you walk along." 4

The notion of internet network neutrality garnered attention after the publication of an article by $\mathrm{Wu}$ (2003). Networks he argues are not like typical businesses that discriminate, and the consequences would be much more severe. That paper suggested legislation to ensure network neutrality.

This set of arguments is not new; it has played itself out in the development of earlier networks. This paper presents evidence about network neutrality, or the lack thereof, in the context of transportation networks. In particular, it illustrates that no other network examined herein has been strictly neutral (in the original $\mathrm{Wu}$, Crawford, Lessig and McChesney (2006) sense of neutral). Rather the Berners-Lee ${ }^{5}$ sense of neutral, which permits differentiated quality of service and different prices, has been closer to practice ${ }^{6}$. Opponents of network neutrality, funded by large telecommunications companies, (in contrast to the large web content companies on the other side of the debate), argue that the internet should not be regulated. ${ }^{7}$ This logic too has arisen in the transport sector, which has swung between unregulated and strictly regulated over the course of time. The issues of common carriage, price discrimination, exclusion and rivalry, and transaction costs are discussed in turn.

\section{Common carriage}

Government regulation has long been an important element of the provision of transportation service, as government permission has been required to construct networks or network elements (for example, bridges, locks, ports, turnpikes, canals), and in some cases public subsidy provided (most notably land grants and powers of eminent domain associated with railroads, in other cases the public purchase of shares or bonds of private network providers). While common carriers have been identified in English Common Law since the 14th century, regulation has since the late 1800s assumed an especially important role, particularly for the then largely mature railroad industry, and many networks become rate-regulated. In the United States, the Interstate Commerce Commission was established in $1887 .^{8}$

\footnotetext{
${ }^{4}$ S. Crawford. "FAQ on Net Neutrality,” May 31, 2006 http://scrawford.blogware.com/blog/_archives/_2006/5/31/1998151.html

${ }^{5}$ T. Berners-Lee “Neutrality of the Net,” May 2, 2006 http://dig.csail.mit.edu/breadcrumbs/node/132

${ }^{6}$ The AT\&T Standard (the conditions imposed upon AT\&T during its merger with BellSouth) permits quality of service differentiation by the customer (consumers can pay more for higher bandwidth), but not the producer (a website cannot pay more to reach customers faster than other websites). That the AT\&T standard also does not discriminate based on "source, ownership, or destination" is consistent with common carriage law, but may be seen as inadequate by advocates of strong neutrality as it does not prevent differentiation by media type or willingness to pay. (Federal Communications Commission, 2006)

${ }^{7}$ Hands Off the Internet. 2006. “About Us,” http://www.internetofthefuture.com/

${ }^{8}$ A Supreme Court case a few decades later noted: "The list of rate-regulated occupations is not too long to be here given. It includes canals, waterways, and booms; bridges and ferries; wharves, docks, elevators, and stockyards; telegraph, telephone, electric, gas, and oil lines; turnpikes, railroads, and the various forms of common carriers, including express and cabs. To this should be added the case of the innkeeper (as to which no American case has been found where the constitutional question as to the right to fix his rates has been considered), the confessedly close case of the irrigation ditches for distributing water (189 U. S. 439), and the toll mill acts. This, of course, does not include the case of condemnation for governmental purposes or
} 
Bouvier's Law Dictionary (Bouvier, 1856) provides a long description of the rights and duties, and liabilities of common carriers. Common carriers are paid in advance, and in return must deliver the passenger safely to their destination. In general, they also could not charge more than a posted fare. They could of course discount. As any modern traveler knows, when visiting a hotel room and looking at the rates posted on the back of the door, there is usually a large discount between actual prices and maximum prices. There is also a minimum quality of service guarantee (for example, "not to overload the coach with either passengers or luggage" assures a limit to the congestion on the vehicle) associated with common carriage.

Common carriage is a much less stringent notion than strict definitions of network neutrality. It does not prohibit offering a higher quality of service. Examples date from the earliest dates of common carriers providing first, second, and third class services. Most widely known are passenger railroads and airlines, which, while common carriers, differentiate quality of service for different fares. This is discussed in more detail in the section below. Other differentiators include means of payment (the willingness to take credit and open accounts rather than requiring cash prior to delivery as had been required), which helped United Parcel Service differentiate itself from the US Post Office, and speed of delivery, as when one train or bus service is faster than another (for example, express vs. local), but both are provided by the same firm under the same common carrier obligations.

The common carriage definition given above applies to carriers, but similar rules may apply to the physical network itself, modern turnpikes do not discriminate between trucks based on their content (provided their content is not-hazardous, is legal, is driven by a licensed driver, meets weight and size restrictions, and is carried on a legal-sized truck that has paid its taxes and fees). However, the turnpike has not historically guaranteed a speed (though this may be changing, as discussed below). Turnpikes also charge different types of trucks different tolls. At one point, California had 17 different rates for trucks at their toll bridge crossings, a number reduced to six only because the automated vehicle classification system the California Department of Transportation developed to administer electronic tolling could not distinguish many of the categories. It should be noted that railroads did engage in value of service pricing.

Noam (1994) further discusses the history of common carriage and comes to the conclusion that common carriage was unlikely to survive in the telecommunications sector, particularly as telecommunications firms became systems integrators and entered the content arena.

\section{Price discrimination}

Price discrimination is the idea that suppliers charge more to some customers than others. While suppliers do this to maximize profit, it may also be efficiency enhancing, especially if price discrimination is voluntarily selected by the consumer and coupled with service differentiation. One means for doing this is by differentiating quality. Under common carriage, the same vehicle can be divided into different classes of service (first class, second class). Although the classes would depart and arrive in town simultaneously (on a

for roads and ways where no question of rates is involved. There may be other instances not found, but it is believed that the foregoing numeration exhausts the list of what has heretofore been treated as a public business justifying the exercise of price-fixing power against persons or corporations.” (Lamar, 1914). 
given vehicle), first class passengers alight the vehicle first, and get better service along the way, a service selected consumers clearly value otherwise they would not pay the premium. As noted above, even common carriers differentiate quality of service by providing faster speeds for passengers or freight paying a premium.

A second means for doing this is to differentiate customers based on their willingness to pay, for example, when buses give discounts to students (or seniors) to ride the exact same bus at the exact same time. In public transit, this is often pitched with an equity rationale, but movie theatres provide discounts to the same groups with no such pretense.

There are numerous variations and combinations of these two techniques. An example is Priceline, where approximately equivalent services have lower prices, in exchange for less certainty in advance about the quality of service being provided (to go from Minneapolis to Chicago, you may change planes in St. Louis, a significantly out-of-theway transfer point).

Today, a new movement is underway to differentiate roads. High Occupancy Vehicle (HOV) lanes, which only carpools or buses (or oddly, motorcycles) could use, were first deployed in the United States in 1969, and were expanded through the 1990s to the point that there are now over $3200 \mathrm{~km}$ of HOV lanes in the United States. Many of these HOV lanes carry more passengers than general-purpose lanes, but fewer vehicles. As a result, many have excess capacity, even at peak times. As a consequence more vehicles could use HOV lanes without congesting them, and thereby reducing traffic in parallel lanes.

High Occupancy/Toll (HOT) lanes were conceived of by Elliott (1975) in the 1970s, and rediscovered in the 1990s by Fielding and Klein (1993). With the advent of electronic toll collection, transaction fees dropped for tolls both on the part of drivers, who no longer need to stop to be tolled in "open road tolling" and for turnpike agencies, which could reduce staff. While only a handful of HOT lanes are operating as of 2008, a number are being planned for deployment. Seeing the potential HOT lanes, Poole and Orski (2000) published a study calling for networks of HOT lanes (or HOT networks) in major US cities. They conclude the benefits of such a system (including congestion reduction for those not using the system) outweigh the costs. The HOT networks also provide the ability to provide bus rapid transit (BRT) services in metropolitan areas, by providing the high speed limited access routes that give transit a travel time advantage.

Untolled roads in parallel with these tolled roads offer drivers a choice, pay money and save time or pay time and save money. This is a classic choice, pay more, getter better service; pay less, get worse service.

Another transportation example is the Paris Metro, which historically (until the mid1980s) had first class and second class cars, the first class cars would charge twice as much, and passengers would likely get a seat, while in second class, passengers may be standing in very crowded cars. As Odlyzko (1999) has noted, the system is self-regulating, if the first class gets too crowded, people stop paying a premium for the better quality of service. If second class gets too crowded, some people switch to first class. Odlyzko suggested an analog for this for the internet. Bandwidth would be broken into several channels and different prices. Each channel would make a best effort to move its packets, the more channels, the more closely each individual's value of time would be approximated.

An important issue that arises is that users are averse to drowning in a sea of small charges, and many prefer flat rate packages than thinking about each decision on a caseby-case basis. This is rational for users, who have limited time and intellectual resources to 
devote to optimizing small decisions and would prefer to satisfice. User frustration with airlines, who, in what is called yield management, micro-manage pricing so that two travelers in adjacent and equivalent seats pay hundreds (or thousands) of dollars difference in fares, or with cell-phone company rate plans, is notorious.

Other (non-price) discrimination has an invidious history as well in transportation, most infamously in parts of the United States the requirement that blacks go to the back of the bus. The challenge to this, the Montgomery Bus Boycott of 1955-1956 initiated by Rosa Parks, ultimately kicked off the Civil Rights Movement. This is analogous to content discrimination in communications.

\section{Enclosure, exclusion, and rivalry}

By converting some existing roadway capacity to toll lanes, when they were previously free (not paid for directly), the amount of free capacity is reduced, and those users are generally worse off (except for those with a very high value of time, who now find the better service outweighs the additional cost). The perception of equity of new toll lanes depends on whether those lanes were converted lanes or they are new construction. Tolling additional capacity is not resisted nearly as much as tolling what had been seen as free.

This echoes arguments put forward by telecommunications companies that additional services that provide additional choices should be allowed, at higher fees, so long as they do not harm existing users. The risk, in both transportation and telecommunications, is that these existing services somehow come at the cost of existing services, which may be allowed to degrade in some fashion, thereby encouraging consumers to upgrade service just to stay in place. In some transportation systems bypasses put paying customers at the front of the queue for bottlenecks, rather than having everyone queue together (first comefirst serve). While this appears to be additional capacity, that capacity is on a non-critical section of infrastructure. A notable example of this is in airport security lines in the United States, where at many airports, first class passengers can jump the queue to clear security faster because they paid the airline more for their ticket (even though they did not pay more for security, as the security surcharge is a fixed tax per passenger).

Perception of inequity associated with changing social relationships can be the source of significant grievances; there were many riots in the Turnpike era from the late 1600s to the mid 1800s. Between 1839 and 1844, to cite one example from history, there were a series of what were called Rebecca Riots in Wales against the construction of gates and imposition of tolls across roads, that resulted in significant destruction of the toll collection apparatus and buildings, and in one case, murder of a toll collector, by "Rebecca and her daughters”, men dressed in women's clothing to hide their identities (Williams, 1955). In November 2004, there was a riot involving over 1000 police and significantly more rioters in Jieyang City in Guangdong Province, China, when a woman was assaulted by toll collectors after complaining about the toll imposed on her motorbike. ${ }^{9}$

Economists define four types of good based on whether the good is excludable or not, and whether the good is rivalrous or not. Goods that are both excludable (I can charge you for it directly) and rivalrous (my use prevents or interferes with yours) are called private, while goods that are neither excludable nor rivalrous are public, the classic example of

\footnotetext{
${ }^{9}$ F. Markus. 2004. “Toll Dispute Sparks Chinese Riot,” BBC News, 16 November. http://news/bbc.co.uk/1/hi/world/asia-pacific/_4015635.stm
} 
which is national defense. The difficulty in drawing analogies is that roads fall into all four boxes. Private goods need not be privately owned, though typically they are in most sectors of a capitalistic market economy.

\begin{tabular}{|l|l|l|}
\hline & Excludable & Non-Excludable \\
\hline Rivalrous & $\begin{array}{l}\text { Private (e.g. congesting } \\
\text { limited access highway) }\end{array}$ & $\begin{array}{l}\text { Congesting (e.g. congested } \\
\text { city street) }\end{array}$ \\
\hline Non-Rivalrous & $\begin{array}{l}\text { Club (e.g. roads within a } \\
\text { gated subdivision) }\end{array}$ & $\begin{array}{l}\text { Public (e.g. uncongested city } \\
\text { street) }\end{array}$ \\
\hline
\end{tabular}

Table 1: Types of Goods

Road financing differs for several of these categories. In Europe and parts of the US, intercity limited access highways are paid for with tolls charged to users. In many parts of the US, local streets are built by developers, and in some cases are maintained by local homeowners associations, who tax themselves for the privilege. City streets are paid for with a combination of local property taxes and state gas taxes. While state roads and "free" interstate highways are paid for by state and federal gas taxes. Homeowners are often responsible for the cost of sidewalks, and are certainly responsible for their maintenance (snow removal in winter) despite sidewalks being public property. This harkens back to the way roads were historically "financed", the road was simply a right of passage across private property, and was the obligation of the property owner to maintain (Levinson, 2002).

Establishment of property rights in cyberspace, as the enclosure of common grounds and roads in real space, is likely to be a contentious issue. What should be a free commons, what publicly controlled and charged for, and what privately controlled? The rights and expectations of the institutional arrangement in contracts between users and monopolistic providers remain unsettled.

\section{$5 \quad$ Transaction costs}

An efficiency argument against network discrimination considers that the cost of differentiated pricing may outweigh the benefits, because of the transaction costs of implementing toll collection.

With pricing in transportation, an entire infrastructure of toll collection and user differentiation needs to be established, and this is not costless. The MnPass HOT Lane system in the Twin Cities does not recover system operating costs after a year of operation (and may never recover capital costs), while the London Congestion Charge, which now charges the vehicle owner 8 pounds per day to travel in the center of London, before the recent toll increase had enforcement and collection costs of about two-thirds of operating revenue (Prud'homme and Bocarejo, 2005). These examples compare with a less than 1 percent collection cost loss associated with gas taxes (Wachs, 2003).

The degree to which the costs of collection on the internet outweigh the benefits of differentiation depends on the technology of collection, and how much interference it imposes on all packets to read each packet and route it on higher speed or slower speed paths based on its origin or fare class. 
We have long recognized that different types of freight have different priorities (overnight, two-day, and ground are among the choices for shipping); and in transportation, the profession has slowly begun to recognize that same kind of differentiation applies to drivers. Different drivers have different values of time at different times of the day. Thus, the ability to pay a premium and travel at a better level of service during peak times provides a service not generally available, but which may add value to the system and improve overall welfare. There is no reason to believe that different packets do not have different value to different users at different times, some are more urgent than others. If that differentiation can be achieved with a minimum of transaction costs, a net welfare improvement can be obtained. Whether that is the case is an empirical, not a moral, argument.

The implications of this are several, high collection costs for discrimination and per use charging are only valuable if the benefits of the discrimination outweigh the costs. In many examples in transportation, the costs of price discrimination and per-use charging outweigh the benefits by suppressing use and increasing costs (Levinson and Odlyzko, 2008). While this of itself does not necessarily favor a regulatory approach to network neutrality, it suggests providers should be reluctant to engage in non-neutral behavior, as that would increases their costs and reduce their demand (and perhaps profit).

\section{Discussion and conclusions}

Many of the analogies that are used about transportation in the public debate over network neutrality are misleading at best. The internet, like most networks, can be divided into sections: first mile, last mile, and linehaul or backbone. The firms that provide these services are different. Each is a potential bottleneck along the trip from content to consumer. While most capacity is unused most of the time, it is the peak times that are of interest, when differentiation matters most.

A key difference is that local streets are expected to be slower and serve less traffic. On the "last mile" of the internet, this creates a bottleneck. In other words, the "last mile" of roads is seldom rivalrous (except perhaps for on-street parking), while the "last mile" of the internet clearly exhibits rivalry at selected times and locations. Removing this bottleneck by expanding capacity to serve selected traffic can be paid for either by a use charge on either the content providers (who may pass it on to their specific customers), or the content consumers, or an access charge levied on all traffic. A use charge falls on those who benefit. An access charge, while smaller per user, falls both on users who benefit and on users who do not. Claiming that the access charge is inherently fairer (an implicit argument of "Save the Internet") is disingenuous.

While homeowners do pay property taxes to support local streets to access the wider network (just as a consumer subscribes to an ISP to access the wider internet), and shippers pay property taxes on their end, shippers pay gas taxes for all road use in between as well (including taxes on gas consumed on the "access" roads), and tolls if they are using tolled facilities.

In transportation, it is customary that the producer pays the shipper for the cost of shipment (a cost which is then passed back to the recipient/consumer). The shipper pays for the truck and labor, and fuel, and pays fuel taxes on the entire trip. The shipper is partially subsidized by local property owners (including producers and consumers), who 
pay the infrastructure cost of local roads (the "first mile" and "last mile") through property taxes. Shippers then pass this transportation cost back to the consumers who already paid an access charge.

No one source pays for the entire road network, and no one, undifferentiated charge should be expected to pay for internet service, which has associated with it both fixed and variable costs, features congestion at times, and for which a per-use charging infrastructure is costly to implement. For highway networks, it has been shown that there is a costminimizing split between state and local government shares of highway finance, with neither all-state nor all-local funding necessarily the most efficient (Levinson and Yerra, 2002). Although the data for private telecommunications networks are not available in the same way as for public highways, one imagines that there is some appropriate split between charging producers and consumers for the cost of different services, and that split may involve both per-use charges and flat rate access charges, depending on the circumstances.

While much transportation has fallen under the common carrier rubric, there is not a mode of transportation that strictly adhered to a notion of neutrality that prohibited both price and quality of service differentiation. Some network operators were more intrusive than others in understanding their customers' shipments, their characteristics, and their ability to pay. Moreover, different networks offer similar but non-identical services (travel by air vs. passenger rail, for instance). In the beginning, successful networks try to remain simple. As maturity sets in, ensuring profits requires differentiating between customers, who have both different willingness to pay and desire differentiation in quality of service (Garrison and Levinson, 2006). While perceived as inequitable or inefficient, product and price differentiation may also be necessary when users of the system impose different demands on it.

The network service providers, especially those who have a monopoly or share an oligopoly for service would like to overcharge and undersupply to maximize profits. In the absence of significant competition and regulation, they will be able to succeed. The difficulty in regulation is finding an appropriate balance between the needs of the consumer and the needs of the regulated provider, without stifling innovation.

\section{$7 \quad$ References}

Bouvier, J. (1856) A Law Dictionary Adapted To The Constitution And Laws Of The United States Of America And Of The Several States Of The American Union With References To The Civil And Other Systems Of Foreign Law. Childs and Peterson, Philadelphia, Pennsylvania.

Elliott, W. (1975) “The Los Angeles Affliction: Suggestions for a Cure," The Public Interest, 38 Winter, 119-128

Federal Communications Commission (2006) “FCC 06-189: Memorandum Opinion and Order in the Matter of AT\&T and BellSouth Corporation Application for Transfer of Control,” 154-55. 
Fielding, G. J. and Klein, D. B. (1993) "How to Franchise Highways," Journal of Transport Economics and Policy, May: 113-130.

Garrison, W. and Levinson, D. (2006) The Transportation Experience: Policy, Planning, and Deployment. Oxford University Press: New York.

Lamar, J. (1914) “Dissent, German Alliance Ins. Co. v. Lewis, 233 u.s. 389,” United States Supreme Court Case.

Lessig, L. and McChesney, R. W. (2006) "No Tolls on the Internet”, Washington Post, June 8: A23.

Levinson, D. M. (2002) Financing Transportation Networks. Edward Elgar, Northampton, MA.

Levinson, D. and Odlyzko, A. (2008) "Too Expensive to Meter: The Influence of Transaction Costs in Transportation and Communication,” Philosophical Transactions of the Royal Society A: Mathematical Physical and Engineering Sciences 366: 2033-2046.

Levinson, D. and Yerra, B. (2002) "Highway Costs and Efficient Mix of State and Local Funds,” Transportation Research Record, 27-34.

Noam, E. M. (1994) "Beyond Liberalization II: The Impending Doom of Common Carriage,” Telecommunications Policy, 8: 435-452.

Odlyzko, A. (1999) "Paris Metro Pricing for the Internet," Proceedings of the 1st ACM conference on Electronic commerce, pp. 140-147. ACM New York, NY, USA.

Poole, R. J. and Orski, C. (2000) "HOT Lanes: A Better Way to Attack Urban Highway Congestion,” Regulation, 23: 15-20.

Prud'homme, R. and Bocarejo, J.P. (2005) "The London Congestion Charge: A Tentative Economic Appraisal” Transport Policy, 12: 279-287.

Wachs, M. (2003) “A Dozen Reasons For Gasoline Taxes,” Public Works Management \& Policy, 7: 235-242.

Williams, D. (1955) The Rebecca Riots: A Study in Agrarian Discontent. The University of Wales Press, Cardiff.

Wu, T. (2003) "Network Neutrality, Broadband Discrimination," Journal of Telecommunications and High Technology Law, 2: 141-179 